\title{
Aims Methode Perspective Communications to Created Exciting School Environment
}

\author{
Nurhalima Tambunan, M.Kom. \\ Lectue Faculty Islamic CentreUniversity Pembangunan Pancabudi
}

\begin{abstract}
As social beings, humans have always communicated with other peoples. Almost $70 \%$ of life we use to describe. By communicating, we can deliver or express what is in our minds to others, as a communicant. With communication, we also mutual understanding, disseminate knowledge, and to preserve civilization. In a school environment where there is a learning process occurs very close relationship of communication between students and teachers. Teachers deliver all forms of instruction, assignments, directives, either using communication media or not. Communication is very intense this is what makes someone students can more easily understand and be more responsive to the subjects presented. Instead, communication hampered because the teacher could not open the communications space, teachers are less able to explore the ability to ask the student, the student was afraid to ask, and will have implications for other reasons is not right to the learning outcomes. Communication can run well if have the same meaning is conveyed by a communicator (speaker) of the communicant (interlocutors) and raises profound sense, which aims to amend the attitude, behavior opinions.With good communications can create a school environment that is fun, for students, teachers, and stakeholders, can boost learning success
\end{abstract}

Keywords: Environment, Communication, School.

\section{INTRODUCTION}

Learning that is identified by the word "teaching" is derived from the word "teaching" which means that the instructions given to men, to be known (obeyed) coupled with the prefix "pe" and the suffix "an" to "learning", which means the process, act, how to teach or teach so that students want to learn.Learning is an activity that is educational value. Coloring educational value interaction between teachers and students. Interaction educational value because teaching and learning activities are carried out, directed to achieve individual goals that have formulated before the teaching done. Teachers have planned systematically teaching everything activities for the benefit of teaching.Two factors affect the learning process. First, internal factors, namely factor in the emergence of the child, such as health, safety, kamampuan, and interests. Second, external factors, i.e., factors that arise outside of the child, such as cleaning the house, the heat, the environment, and so on. However, any activity, if executed with great interest and excitement, will bring satisfactory results. Likewise with learning. Learning done with keen attention and affection will bring much better results than the study carried out by necessity.Generating interest in learning in children so that learning becomes a hobby seems to be an important aspect which should be fostered and developed by the children, by parents and teachers. This can do through the creation of a pleasant school environment in a communications perspective.Therefore, parents and teachers should make efforts to systematically and accurately generate interest in this study. One of the fundamental aspects that should be an essential foundation is looking at children with the right perspective. Many parents and teachers assess children with an adult paradigm. Within this framework, when communicating with the kids, an important aspect to be notified not tell something that is considered good from the perspective of adults, but sat together with the children, to empathize, to accompany, and create an atmosphere of fun for children. By communicating this kind, the child feels appreciated. In the context of learning, using empathetic communication will make learning with parents is not a daunting and burdened, but became enjoyable playing experience.The world's children are typical of the world. They have a perception, imagination, and views that differ from their parents. The life they live is different from life as lived by their parents or teachers. Changes have been taking place in the lives quickly. This difference is often cause tension between parents or teachers and children. Children with the ideal childish world often perceive something simple, but often become very complicated in the eyes of parents. Because they can not or will not understand the child, parents often unwittingly imposing its perception on the child. The average child is finally willing to follow the will of their parents, but without realizing the child could lose the distinctiveness of her childhood.In many cases, parents build imagination, hope, and pride of their children ideal. For example, children were "forced" to less particular, forced school children in the majors according to their parents and prospective kind, are required to become a champion, and so forth. Expect the ideal sort of thing does not mean 
not to be. However models in making this happen they should be tailored to the child's condition, not by coercion.Ideally children learn with the spirit that grows from within him. Children who learn because of the pressure it would be difficult to enjoy the process of learning to do. Indeed, many children who have grown consciousness to learn. In children with this kind does not mean the duty of parents about children's learning has completed. Because her son had diligently studied every day, folks consider it has been successful and keep silent without any concern or assistance at all. Kids, however unyielding internal motivation to learn, still requires an environment conducive to learning and enjoys what he learned.Parents can play a role in creating an atmosphere that encourages children to enjoy learning, by providing security and psychological freedom in children. Three interconnected processes can form psychological safety. First, parents accept their child as with all the advantages and limitations. Second, parents cultivate an atmosphere in which there are no dangerous effects. Third, parents give sense to look at the child's condition, participate live, and get to know your child's feelings, their thoughts, actions and can view from the perspective of a child.Proper communication in guiding children will make the son of a man with qualities that continue to grow with the growing interest in learning about him. Creating a pleasant school environment is critical. In this method due to the creation of a school environment that is fun would help the vision of the school itself. To realize this vision, the need for attention, concern, and cooperation of all elements (stakeholders) of the start of the leader / principal, teachers, students, parents, school committees and the surrounding community as a supporter of education.To realize the kind cooperation of the various elements is certainly very necessary to have excellent communication and useful and educative in any activities, socialization, attitudes, behavior and body language.

\section{A. Communication.}

\section{Meaning of Communication.}

The term communication or communication in English is derived from the Latin word communication and comes from the word that means the same communities. Same here means the same meaning. Terminology communication according to Kincaid is a process of information exchange is performed by two or more people, which in turn led to a deep mutual understanding. Among Uchjana Effendi suggested that the paradigm of communication is so widespread and is the process of delivering a message to one person to another to notify (inform a message to the client) or to change the attitudes, opinions or behavior, either verbally, or indirectly through the media.In a letter to the communicant, communicator usually, expensive communication techniques should be used for the purpose of effective communication. Without considering and selecting the appropriate communication methods, the desired objectives can not achieve to the fullest. In the sense of the word, the communication process is done a failure, due to the lack of understanding of being communicated.

\section{Communication Objectives}

The objectives of the communication is as follows:

A) Changes in Attitude (Attitude change)

Changes tendency to behave to an object for their motivation from within themselves and their environment

B) Changes opinion (Opinion change)

Changes which a person change his opinion. Usually, this view changes caused by discrepancies in opinion between fellow friends or family or actions to support our conclusion that for example at the meeting.

C) Changes in behavior (Behavior change)

Change in behavior is the behavior change that is often experienced by someone for their encouragement of others and does not also forget from ourselves.

D) Changes in social (social change)

Changes that occur in a social environment or social environment of the social system

\section{Elements of Communication}

The elements of the communication is as follows:

-.Comunicator (Person delivering the message)

- Communicant (the person acting as the listener)

- Messages (information sent by the sender)

- Feed back (reciprocal feedback delivered by the communicator,

to amend the opinion or purpose of communication itself

\section{Communication Techniques}

The techniques in communication are as follows:

a) Informative Communications (Informative Communication)

Communications that are information or notification

b) Persuasive Communication (Persuasive Communication) 
Convincing itself can define as the process of influencing and controlling the behavior of others through psychological approach

c) Instructive Communications (Instructive communication)

Communication do in the form of instructions or orders, such as supervisors and subordinates

d) Human Relations (Human Relations)

\section{2. Communication Ethics}

Procedures for the association, rules of behavior, customs of human society and determine the value of good and not good value, called ethics. The term comes from the word ethics echinus (Latin) and in Greek is called ethicos which mean the habit of norms, values, rules and measures of good and bad human behavior.

So, ethical communication is the norm, value or size of good behavior in communication activities in a society in this regard is the ethics of communication within the school environment or education.

Communication in the school environment is a process of communication between leaders, teachers, students. Its method keeps communication process runs well, so as not to cause an adverse impact, it is necessary to communicate ethics. The easiest way is to apply the principles of school communication, all elements of the school should consider the following points:

1. Manners good relationships

2. Norma decency and morality

3. Norma decorum in all actions

If the ethics and etiquette apply anywhere and anytime, then within the scope of this, communication with others in the association community and the lives of others is an arena which is demanding quota implementation of ethics. Because there are people who say that between ethics and communication in the association are the two things that can not be separated. Wherever people communicate, always requires an ethical consideration, so that the other person can receive it well. Communicating is not always easy, especially if we do not know the identity of those who we face, we would be guessing and designing preparation of communication within their ethical demands of both sides. When we are aware of the character of our people we deal with will be easier trying to showing prepare well in communicating.

\section{B. Environment Exciting}

\section{Understanding the School Environment}

School environment or commonly referred to as the educational environment are all conditions and influences from outside the activities. This opinion means that the school environment or education environment

2. Environmental Indicators School Exciting

School as a place of fun for students will reflect in the various indicators. Among others: the learning process, the physical and social environment, the rules of the school and extracurricular activities. Let's continue to discuss it one by one.

\section{a. Learning process}

The learning process in the classroom (intro) and outside the classroom (extracurricular) delightful student. They feel at home in the classroom to follow study process. Professional Teachers and adequate learning facilities, an essential element in creating a fun learning environment for students.

\section{b. School Physical Environment}

The physical environment of the school is clean, orderly, neat and green will make students feel comfortable in the school. Classroom learning feels comfortable. Parks classroom and school environment green garden will make citizens become fresh mind.

\section{c. social environment}

Neighborhood social interaction among people in schools will determine the school as a happy place. The maintained school maintained harmonious social relationships and communications between teachers and school principals, Teacher and students and among's. They will learn always to be in school every day.

\section{d. school discipline}

At school there are a set of rules and discipline of students, teachers, and other personnel. The rules and regulations along with the sanctions and penalties. Violations and irregularities against the rules and regulations trip school will face sanctions and penalties that create an environment of awareness comply with all the rules and regulations of the school. 


\section{e. extracurricular activities}

Extracurricular activities sometimes become a brand of a school. A school became famous precisely because of extracurricular activities. Especially schools that have many smart and reliable management. Management school will accommodate any potential interests and talents of students by organizing events extracurricular activities program that diverse.Membangun Komunikasi yang baik antar guru, siswa dan orang tua.

\section{a) Communication between teachers and students}

Failure in a learning process very often come across this sort of thing. Failure in teaching and learning activities in general due to factors that not reinforced communication. Weak disclosure in the classroom to make education in trouble in managing the class of things of this kind should avoid so that failures in the learning process does not happen again. Things we need to do to minimize failures in the learning process by mastering how to communicate in the classroom. To develop communication in the classroom so that learning objectives getting there are some patterns of communication that we need to know and applied at the same time we grow:

- Communication as an actor a one-way communication (communication of this type requires teachers to play an active role to take action in the matter and student members a role as a work. For example, a lecture.

- Communication as a two-way interaction or communication. Namely the participation of all members of the class both teachers and students. Educators and students can act together, as a recipient action .never action and only the teacher who gives the effect but with communication in students can also serve as action

- Communication lot of direction or communication is communication as a transaction involving teacher interaction with students and students with other students.

Five strategies need to be developed to build effective communication among

a. Respect

Mutual respect will make someone means that he felt comfortable and would turn appreciate the people who have given him awards

b. empathy

an ability to put themselves to the situation perceived by others.

c. Audible

Can be heard or understood. How good delivery would be more readily accepted, heard from those using complicated language.

d. obvious meaning

A teacher does not use a double meaning at the time of conveying the problems of the students.

e. Humble

Meaning if one appreciates the work of the students.

\section{a) personal communication Between Teachers and Parents}

Failure to establish communication with the parents about the child's progress in school, then we will lose the chance to create a bridge of communication is critical in the lives of learners. The importance of communication between parents and teachers, especially to ensure that children learn effectively and get the best for the growth and development of the private / their characters.

There is one way to ensure that we as teachers can communicate properly is to use the form and notes are sent home periodically to provide opportunities for parents to monitor complaints against their children's development at school.

As for the parents who are too busy or reluctant to contact the teachers and the teachers should take the initiative. Several things need to considered to communicate effectively with parents

- To communicate as often as possible

- Be honest (call parents when their child has behavioral or learning difficulties in class)

- Stay organized (when talking with parents about them, they are only reallyinterested in their child, not the entire class).

- Plant the impression that we are interested in their child.- An opportunity of time.

\section{CONCLUSION.}

In social life, there is a system which regulates the procedures for humans to get along. Procedures for the association for the mutual respect we used to know as manners, etiquette, protocol, and others.

Procedures for the organization aims to safeguard the interests of communicators with communicant to feel happy, peaceful, protected without any aggrieved party interests and actions undertaken by the prevailing customs and do not conflict with human rights in general 


\section{DAFTAR PUSTAKA}

Syaiful Bahri dan Aswan Zain, Strategi Belajar Mengajar,Jakarta: PT Rineka Cipta, 2010.Hamzah B. Uno \& Nurdin Mohamad, Belajar dengan Pendekatan PAILKEM, Jakarta: Bumi Aksara, 2012.Ngainun Naim, Dasar-dasar Komunikasi Pendidikan, Yogyakarta: Ar-Ruzz Media, 2010Onong Uchjana Effendy, Ilmu Komunikasi Teori dan Praktek,Bandung: PT. Remaja Rosdakarya, 2011Hafied Cangara ,Pengantar Ilmu Komunikasi, Cet. 6 Jakarta : Raja Grafindo Persada, 2005Effendy, Dinamika Komunikasi, Cet. 4. Bandung : Remaja Rosdakarya. 2000.Jalaluddin Rakhmat, Psikologi Komunikasi, Bandung: PT Remaja Rosdakarya, 2011. 